\title{
Body mass index, total cholesterol, and ratio total to HDL cholesterol were determinants of metabolic syndrome in the Indonesian elderly
}

\author{
Sudijanto Kamso
}

\begin{abstract}
Abstrak
Ketersediaan data tentang faktor-faktor yang berhubungan dengan metabolik sindrom pada kelompok lanjut usia di Indonesia sangat terbatas. Data tersebut sangat diperlukan dalam upaya pencegahan penyakit kardiovaskular. Tujuan penelitian ini untuk mengetahui prevalensi metabolik sindrom dan hubungan pengukuran antropometrik, profil lipid, tekanan darah, asupan makanan dan aktifitas fisik dengan metabolik sindrom pada kelompok lanjut usia. Suatu studi dengan rancangan 'cross sectional' dilakukan di Jakarta dengan menggunakan metoda 'multistage random sampling'. Jumlah responden 352 orang lanjut usia wanita dan 137 orang lanjut usia pria. Pengumpulan data dilakukan dengan pengukuran antropometri, analisa biokimia darah, analisa asupan makanan dan pengukuran indeks aktivitas. Prevalensi metabolik adalah $18.2 \%$ pada lanjut usia wanita dan $6.6 \%$ pada lanjut usia pria. Studi ini menunjukkan bahwa pada lanjut usia yang mempunyai berat badan berlebih, risiko untuk mempunyai metabolik sindrom hampir empat kali lebih tinggi dibanding lanjut usia dengan indeks masa tubuh normal (rasio odds suaian $=3.98$; 95\% confidence interval 2.23 - 7.10). Lanjut usia dengan plasma total kolesterol $\geq 240 \mathrm{mg} / \mathrm{dl}$, risiko untuk mendapatkan metabolik sindrom $2.7 \mathrm{kali}$ lebih tinggi dibandingkan yang mempunyai plasma total kolesterol $<240 \mathrm{mg} / \mathrm{dl}$. Sementara lanjut usia yang mempunyai rasio total kolesterol terhadap $H D L$ kolesterol $\geq 5$, risiko untuk menderita metabolik sindrom dua kali lebih tinggi dibandingkan yang rasionya $<5$. Studi ini menunjukkan bahwa pemeriksaan profil lipid, pengukuran tekanan darah dan pengukuran antropometrik sederhana yang teratur pada kelompok lanjut usia penting dilakukan untuk mendeteksi risiko terjadinya sindroma metabolik. (Med J Indones 2007; 16:195-200)
\end{abstract}

\begin{abstract}
Available data on metabolic syndrome amongst the aged Indonesian population are limited, despite the importance of these data for cardio vascular disease (CVD) preventive measures. The objective of this study was to assess prevalence of metabolic syndrome and the associations between anthropometric measurements, lipid profiles, blood pressure, nutrient intakes and physical activity and metabolic syndrome in the elderly. A cross-sectional study was undertaken from January to April 2000 at selected Public Health Centers in Jakarta using multistage random sampling. Data were collected through anthropometric measurements, biochemical blood analysis, nutrient intake assessment and activity index. The subjects consisted of 352 females and 137 males. Prevalence of metabolic syndrome among females was $18.2 \%$ and $6.6 \%$ in males. This study shows metabolic syndrome was associated with gender, body mass index, total cholesterol and the ratio of total to HDL-cholesterol. Elderly who were overweight based on body mass index (BMI) had almost a four-fold increased risk for metabolic syndrome (adjusted odds ratio $=3.98$; 95\% confidence interval 2.23 - 7.10). Those who had plasma total cholesterol $\geq 240 \mathrm{mg} / \mathrm{dl}$ had a 2.7 times greater risk of having metabolic syndrome than those with plasma total cholesterol $<240 \mathrm{mg} / \mathrm{dl}$. Furthermore, in terms of the ratio of total to HDL cholesterol, those who had a ratio $\geq 5$ compared to a ratio $<5$ had two-fold increased risk for metabolic syndrome. In conclusion, this study shows the importance of routine checks of lipid profile, blood pressure and simple anthropometric assessment to detect the risk of metabolic syndrome in the elderly. (Med J Indones 2007; 16:195-200)
\end{abstract}

Keywords: metabolic syndrome, elderly, gender, body mass index, cholesterol

The Indonesian Household Survey showed that the highest prevalence of cardiovascular diseases (CVD) and hypertension was amongst individuals aged 55 and older. Among CVD, the prevalence of hypertension was the highest. ${ }^{1}$ Results of the WHO - Five

Department of Population and Biostatistics, Faculty of Public Health, University of Indonesia, Depok, Indonesia
Country Study of Health of the Elderly in the Community (MONICA), Indonesia country report, also revealed that hypertension was the most prevalent of CVD, followed by coronary heart disease (CHD). ${ }^{2}$

On the other side of the coin, available data on CVD risks amongst Indonesian aged population are limited, despite the importance of these data for preventive measures. Identification of CVD risks or determinants 
and their interplays is crucial for successful preventive intervention. Coronary heart disease, hypertensive heart disease (HHD), and stroke are the main causes of morbidity and mortality in the elderly in Indonesia, both in hospital and community settings. Elderly with myocardial infarction had higher mortality rates than their younger counterparts. The mortality rate of CVD (per 100.000) for Indonesia (urban and rural) in 1995 was 67.8. ${ }^{1,3}$

Epidemiological studies in middle-aged men have clearly demonstrated that elevated serum cholesterol is a major risk factor for coronary heart disease. There appears to be no threshold level below which serum cholesterol ceases to predict coronary heart diseases, while the risk increases markedly when cholesterol values exceed $200 \mathrm{mg} / \mathrm{dl}$. If the coronary heart disease risk is set at 1 for a cholesterol level of $200 \mathrm{mg} / \mathrm{dl}$, the risk is doubled at $250 \mathrm{mg} / \mathrm{dl}$ and increased by four times at $300 \mathrm{mg} / \mathrm{dl}$. ${ }^{4,5}$

Degenerative disease like coronary heart disease was previously recognized as related to over-nutrition. It is now well documented to be related to several aspects of risk factors, such as fat mass, lipid profile, nutrient intake and life style. It is, therefore, timely to have abetter understanding of the relationship of fat mass, lipid profile and life style indicators with metabolic syndrome in the Indonesian elderly.

The aim of this study was to assess the prevalence and determinants of metabolic syndrome in the elderly population.

\section{METHODS}

This study was conducted from January to April 2000 in 15 sub-district health centers in Jakarta, using a cross-sectional method. Respondents were taken from a population of 2500 elderly who joined the health centre program and registered as guided elderly. The selection of the elderly subjects for the study was done at the Municipality and Public Health Center level using multistage random sampling 15 subdistrict Public Health Centers in the municipality were selected. Elderly individuals from each Public Health Center were listed and numbered, and random sampling was performed until the size of the sample was 40 . The inclusion criteria were: 55 - 85 years old and apparently healthy and ambulatory. Exclusion criteria were: bedridden, physically handicapped, unable to come to the public health centre, or having any condition, such as mental illness, which would make the elderly, in the opinion of the principal investigator, unsuitable for the study.
Risk factors analyzed in this study were: waist circumference, serum total cholesterol, LDL-cholesterol, HDL-cholesterol, triglycerides, fasting glucose, body mass index, systolic blood pressure, diastolic blood pressure, fat mass percentage, sum of skin-folds, smoking, activity index, stress score, energy intake, and fat intake and fiber intake.

Fasting blood samples were taken from the subjects and biochemistry analysis was conducted in the Regional Health Laboratory. Anthropometric assessment was conducted according to standard procedure. Body weight was measured in an upright position to the nearest $0.1 \mathrm{~kg}$ using a SECA electronic scale (model 770 alpha, Hamburg, Germany). Subjects were weighed without shoes and with minimum clothing. Height was measured in an upright position to the nearest $0.1 \mathrm{~cm}$ using a microtoise.

All measurements were done twice, and the average was used for further analysis. Serum total cholesterol was measured using the cholesterol oxydase method supplied by Boehringer, LDL cholesterol was measured using the precipitation polyvinyl sulfate (PPS) method, and serum triglycerides were measured using an enzymatic test.

Dietary 24-hour recall method was applied to estimate daily nutrient intakes. The World Food 2, Dietary Assessment System developed by INFOODS (the International Network of Food Data Systems) and the University of California was used to convert foods into nutrients.

The Baecke Physical Activity Scale (using questionnaire) was used to measure the physical activity index (daily activity score) of the respondent, and it consisted of the Works Index, Sport Index and Leisure Index. ${ }^{6}$ The physical activity index was divided into three categories: < 5.6 (low activity); 5.6-7.9 (middle activity); > 7.9 (high activity). Life style factors in this study were represented by physical activity.

The diagnosis of metabolic syndrome was based on the National Cholesterol Education Program criteria modified for Asians (NCEP ATP III). The NCEP ATP III defined metabolic syndrome as the presence of three or more of the following risk factors: 1) increased waist circumference ( $>90 \mathrm{~cm}$ for men, $\geq 80 \mathrm{~cm}$ for women); 2) elevated triglycerides ( $\geq 150 \mathrm{mg} / \mathrm{dl}$ ); 3) low HDL cholesterol ( $<40 \mathrm{mg} / \mathrm{dl}$ in men, $<50 \mathrm{mg} / \mathrm{dl}$ in women); 4) hypertension ( $\geq 130 / \geq 85 \mathrm{mmHg}$ ); and 5) impaired fasting glucose $(\geq 110 \mathrm{mg} / \mathrm{dl}){ }^{7}$ 
Part of the problem with the NCEP definition of obesity is that the cutoff points used to define obesity in both men and women are not valid for people from Europe and Asia. In general, Asians have a lower body mass index (BMI) and waist circumference but can still have high insulin resistance. The International Diabetes Federation recently published consensus cutoff points for waist circumference, $\geq 90 \mathrm{~cm}$ for south Asian men and $\geq 80 \mathrm{~cm}$ for south Asian women, that are more ethnic-specific. ${ }^{8}$ In this study, waist circumference as one component of metabolic syndrome, was modified to use the International Diabetes Federation criteria, instead of $>102 \mathrm{~cm}$ for men and $>88 \mathrm{~cm}$ for women as stated in the NCEP definition of obesity.

A multivariate logistic regression analysis using SPSS 13 software was performed to examine the dominant risk factors related to metabolic syndrome.

\section{RESULTS}

The response rate in this study was $81.5 \%$. Non-responses were mostly due to the distance subjects lived from the community health centre, where measurements of lipid profile, blood pressure and anthropometric were conducted.

The data from 489 elderly respondents, consisting of 352 women and 137 men, were available for analysis. In general, the prevalence of metabolic syndrome was
$14.9 \%$. Elderly women had a higher prevalence rate than elderly men ( $18.2 \%$ and $6.6 \%$ respectively).

Table 1 shows that more women than men had increased waist circumferences and elevated triglycerides. On the other hand, more men than women had impaired fasting glucose and hypertension.

Table 1. Prevalence of metabolic syndrome components in the elderly population by gender

\begin{tabular}{lcc}
\hline Metabolic syndrome components & Women & Men \\
\hline Increased waist circumference & $237 / 395$ & $59 / 161$ \\
(men $>90 \mathrm{~cm}$, women $>80 \mathrm{~cm})$ & $(60 \%)$ & $(36.6 \%)$ \\
Elevated triglycerides $(\geq 150 \mathrm{mg} / \mathrm{dl})$ & $129 / 306$ & $37 / 95$ \\
& $(42.2 \%)$ & $(38.9 \%)$ \\
& $112 / 306$ & $18 / 95$ \\
Low HDL cholesterol $(<40 \mathrm{mg} / \mathrm{dl}$ & $(36.6 \%)$ & $(18.9 \%)$ \\
in men, $<50 \mathrm{mg} / \mathrm{dl}$ in women) & $47 / 122$ & $26 / 48$ \\
Impaired fasting glucose & $(38.5 \%)$ & $(54.2 \%)$ \\
( $\geq 110 \mathrm{mg} / \mathrm{dl})$ & $256 / 395$ & $115 / 161$ \\
Hypertension $(\geq 130 / \geq 85 \mathrm{mmHg})$ & $(64.8 \%)$ & $(71.4 \%)$ \\
\hline
\end{tabular}

Table 2 shows that metabolic syndrome cases and normal subjects were similarly distributed with respect to income, higher education, energy intake of 2000 or more calories, and physical activity level. Furthermore, the subjects aged 60 years or more, education level of 6 to 12 years, and energy intake less than 1300 calories had increased risk to experience metaboloc syndrome.

Table 2. Some demographic characteristics, energy intake, physical activity and risk of metabolic syndrome in the elderly

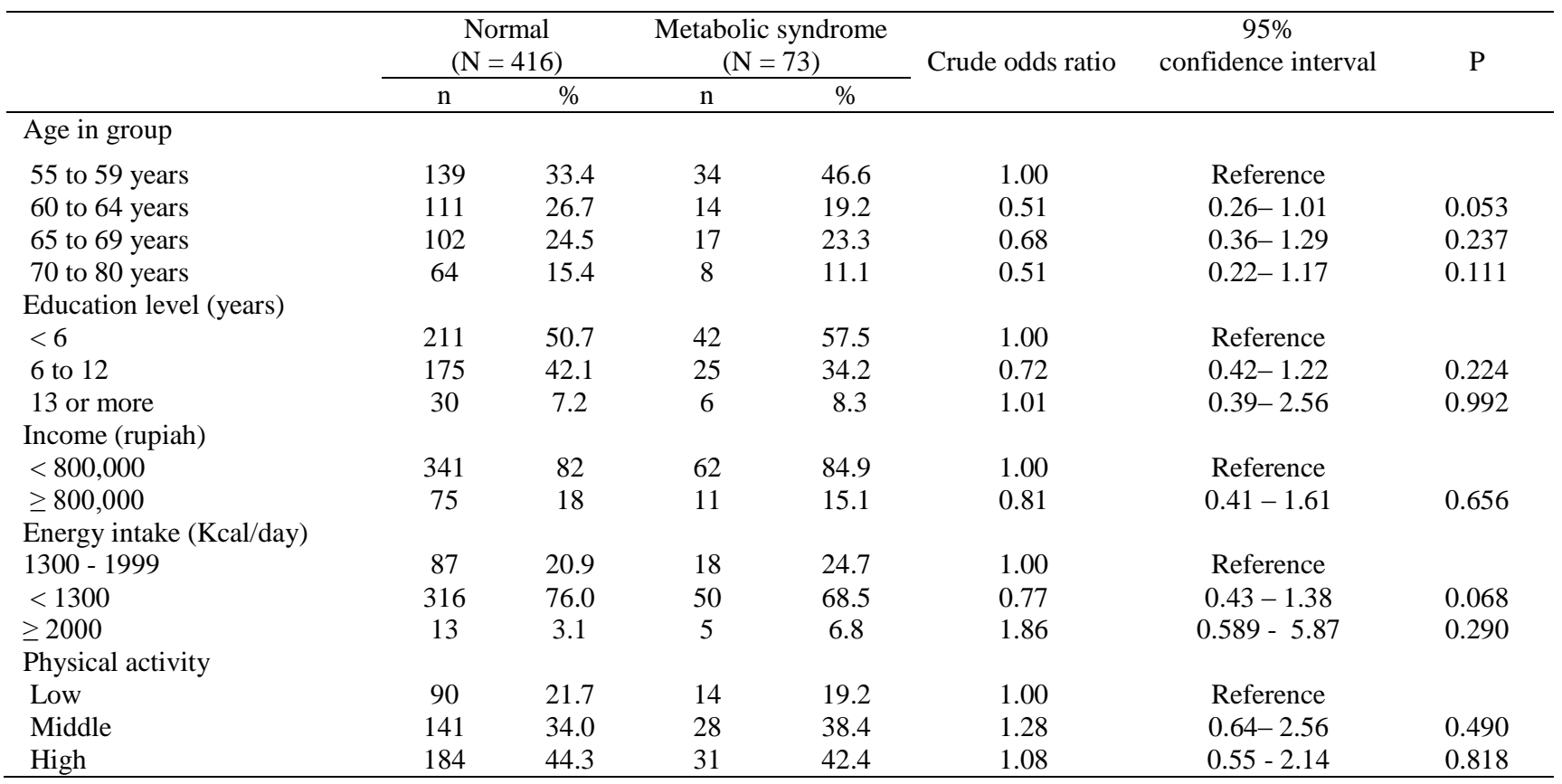


The final model (Table 3) shows metabolic syndrome was related to body mass index, total cholesterol and the ratio of total cholesterol to HDL-cholesterol.

Elderly men were 59\% less likely than women to have metabolic syndrome. In terms of body mass index, the elderly who were overweight had almost a four-fold increased risk for metabolic syndrome. (Odds ratio $=$ 3.98; $95 \%$ confidence interval $2.23-7.10$ ). In terms of plasma total cholesterol, those who had plasma total cholesterol $\geq 240 \mathrm{mg} / \mathrm{dl}$ were 2.7 times more likely to have metabolic syndrome than those with plasma total cholesterol $<240 \mathrm{mg} / \mathrm{dl}$. Furthermore, in terms of the ratio of total cholesterol to HDL cholesterol, those who had a ratio greater than five to one had a two-fold increased risk for metabolic syndrome.

\section{DISCUSSION}

In interpreting the findings of this study, there are several limitations. Firstly, this study population was limited to elderly who joined the health centre program and registered as guided elderly, not from all free living elderly; secondly, the proportion of subjects was more female than male; thirdly, the risk factors analyzed in this study were limited to anthropometric measurement, lipid profile, blood glucose, blood pressure, nutrient intakes, physical activity and some demographic characteristics. One factor that should be taken into consideration is the different criterion of elderly for this study. Subjects are as young as 55 years, the age when most government employees in Indonesia retire, while in other countries the criterion of elderly begins at 60 years or 65 years old.

In many studies observing various determinants of metabolic syndrome in the elderly population, a question which often arises is what are the key factors determining the occurrence of metabolic syndrome? The interplay between nutritional factors and metabolic syndrome has been discussed in many studies. ${ }^{9}$ However; further questioning is appropriate on whether there are other factors which are more prominent than nutritional factors in the elderly population, leading to the occurrence of metabolic syndrome. The WHO Scientific Group reported that both nutritional and non nutritional factors such as physical activity, alcohol and stress can be additional risks for the occurrence of metabolic syndrome. ${ }^{10}$ Therefore; attention should be paid to all of the important risk factors rather than concentrating on one single risk factor.

The primary purpose of this study was to investigate various determinants of metabolic syndrome in the Indonesian elderly, by observing fat mass indicator, anthropometric indicator, lipid profile, nutrient intake, life style indicator and their interactions.

This study showed that, in general, the prevalence of metabolic syndrome defined as a combination of increased waist circumference and elevated triglycerides and hypertension in the elderly was $14.9 \%$. Elderly women had higher prevalence of metabolic syndrome than men.

Table 3. Relationship between body mass index, total cholesterol, ratio total cholesterol/HDL cholesterol and risk of metabolic syndrome in the elderly

\begin{tabular}{|c|c|c|c|c|c|c|c|}
\hline & \multicolumn{2}{|c|}{$\begin{array}{l}\text { Normal } \\
(\mathrm{N}=416)\end{array}$} & \multicolumn{2}{|c|}{$\begin{array}{c}\text { Metabolic Syndrome } \\
(\mathrm{N}=73)\end{array}$} & \multirow[t]{2}{*}{$\begin{array}{l}\text { Adjusted odds } \\
\text { ratio* }\end{array}$} & \multirow{2}{*}{$\begin{array}{c}95 \% \\
\text { Confidence } \\
\text { interval }\end{array}$} & \multirow[t]{2}{*}{$\mathrm{P}$} \\
\hline & $\mathrm{n}$ & $\%$ & $\mathrm{n}$ & $\%$ & & & \\
\hline \multicolumn{8}{|l|}{ Gender } \\
\hline Women & 288 & 69.2 & 64 & 87.7 & 1.00 & Reference & \\
\hline Men & 128 & 30.8 & 9 & 12.3 & 0.41 & $0.19-0.89$ & 0.025 \\
\hline \multicolumn{8}{|l|}{ Body Mass Index } \\
\hline $18.5-24.9 \mathrm{~kg} / \mathrm{m}^{2}$ & 243 & 58.4 & 21 & 28.8 & 1.00 & Reference & \\
\hline$<18.5 \mathrm{~kg} / \mathrm{m}^{2}$ & 43 & 10.3 & 1 & 1.4 & 0.42 & $0.05-3.34$ & 0.415 \\
\hline$>25 \mathrm{~kg} / \mathrm{m}^{2}$ & 130 & 31.3 & 51 & 69.8 & 3.98 & $2.23-7.10$ & 0.000 \\
\hline \multicolumn{8}{|l|}{ Total Cholesterol } \\
\hline$<240 \mathrm{mg} / \mathrm{dl}$ & 149 & 45.4 & 18 & 24.7 & 1.00 & Reference & \\
\hline$\geq 240 \mathrm{mg} / \mathrm{dl}$ & 179 & 54.6 & 55 & 75.3 & 2.67 & $1.44-4.94$ & 0.002 \\
\hline \multicolumn{8}{|c|}{$\begin{array}{l}\text { Ratio Total Cholesterol/HDL } \\
\text {-cholesterol }\end{array}$} \\
\hline$<5$ & 239 & 72.9 & 43 & 58.9 & 1.00 & Reference & \\
\hline$\geq 5$ & 89 & 27.1 & 30 & 41.1 & 2.05 & $1.16-3.63$ & 0.015 \\
\hline
\end{tabular}

* Adjusted each others for listed risk factors on this table 
The prevalence of metabolic syndrome found in this study is different from other studies conducted in other Asian countries, most likely because different criterion is used in diagnosing metabolic syndrome. A study of the urban Korean population aged 30-80 years showed the prevalence of metabolic syndrome was $16.0 \%$ in men and $10.7 \%$ in women. ${ }^{11}$

From a public health point of view, using the lower NCEP ATP III criterion of hypertension, SBP $\geq 130 \mathrm{mmHg}$ and DBP $\geq 85 \mathrm{mmHg}$, as a component of metabolic syndrome, has an advantage, since the magnitude of the problem could be detected earlier. This has implications for establishing a better public health oriented program on hypertension and metabolic syndrome.

One of the most easily recognized consequences of over-nutrition is obesity, which is a risk factor for other diseases such as non-insulin-dependent diabetes mellitus, cardiovascular disease and hypertension. There is a positive association between metabolic syndrome and indices of "fatness" such as body mass index (BMI), and sum of skin-folds. It is reported that waist circumference, an indirect index of abdominal adiposity, is positively related to both systolic and diastolic blood pressure and thus, increased waist circumference has been shown to be hazardous to health. ${ }^{12-13-14}$ This study shows that the risk of elderly with $\mathrm{BMI} \geq 25 \mathrm{~kg} / \mathrm{m}^{2}$ having metabolic syndrome was 4.25 times higher than those with $\mathrm{BMI}<25 \mathrm{~kg} / \mathrm{m}^{2}$.

The Framingham Study reported that obesity was shown to be one of the major determinants of hypertension in the general population, and central deposition of body fat was a more important predictor of hypertension than peripheral fat deposition. ${ }^{15}$

In this study, logistic regression analysis demonstrate a strong correlation between body mass index (BMI), serum total cholesterol, and the ratio of total cholesterol to HDL cholesterol with metabolic syndrome.

The importance of hypercholesterolemia as a risk factor for cardiovascular disease in middle-aged people suggests that cholesterol-lowering therapy should be used to prevent morbidity and mortality. The risk of having cardiovascular disease is doubled at $250 \mathrm{mg} / \mathrm{dl} .{ }^{4}$ This study shows that the risk of elderly with plasma total cholesterol $\geq 240 \mathrm{mg} / \mathrm{dl}$ having metabolic syndrome was 2.75 times higher compared to those with plasma total cholesterol $<240 \mathrm{mg} / \mathrm{dl}$. And the risk of elderly with ratio total cholesterol/HDL cholesterol $\geq 5$ having metabolic syndrome was 2.1 times higher compared to those with ratio total cholesterol/HDL cholesterol $<5$.

The multiple metabolic abnormalities clustered in hypertension are important in relation to prognosis and therapy. The most recent World Health Organization/ International Society of Hypertension guidelines for the management of mild hypertension give considerable attention to the global assessment of cardiovascular risk in patients with hypertension and stress that, among individuals with mild hypertension, the risk of serious cardiovascular disease is also determined by a variety of risk factors other than blood pressure. The higher the absolute risk, the greater is the absolute benefit brought about by lowering blood pressure and correcting other risk factors, such as dyslipidemia. ${ }^{16}$

Elderly with one or more metabolic syndrome components, which was found to be quite high in this study, will have a higher risk of serious cardiovascular disease. ${ }^{17-18}$ The public health implication of this problem is that detection programs on the components of metabolic syndrome and public health education is really urgent.

In conclusion, metabolic syndrome is a problem in the Indonesian elderly. Routine regular check ups of plasma lipids, blood pressure and especially maintenance of an optimal weight for the elderly are important factors preventing the emerging of metabolic syndrome. Therefore, it is recommended for health care providers as well as society to look after and control the above mentioned factors to prevent an increase in the prevalence of metabolic syndrome in the elderly.

\section{Acknowledgement}

The author thanks all the subjects for the cooperation and participation in this study. Special gratitude to Prof. Bastaman Basuki for technical assistance. Lastly to Dr. Elisabeth Emerson (Minnesota, USA) for reviewing and editing the earlier drafts of this manuscript that improve the final product.

\section{REFERENCES}

1. Ministry of Health of the Republic of Indonesia. Household health survey. Jakarta. The Ministry. 1995.

2. National Cardiovascular Center. Indonesian Cardiovascular Study - Jakarta III. Jakarta. The Center. 2000.

3. Boedhi-Darmojo. Rural community cardiovascular study [Indonesian]. Medika. 1996;6:450-7. 
4. Weverling-Rijnsburger, Blauw GJ, Lagaay AM, Knook DL, Meinders AE, Westendorp RGJ. Total cholesterol and risk of mortality in the oldest old. $\mathrm{N}$ Engl J Med. 1997;350: 1119-23.

5. Oliver MF. Linoleic acid, antioxidants and coronary heart disease. Biochem Soc Trans. 1990;18:1049-51.

6. Baeke JA, Burema J, Frijter JE. A short questionnaire for the measurement of habitual physical activity in epidemiological studies. Am J Clin Nutr. 1982;36:936-42.

7. Expert Panel on Detection, Evaluation, and Treatment of High Blood Cholesterol in Adults. Executive Summary of the Third Report of the National Cholesterol Education Program (NCEP) Expert Panel on Detection, Evaluation, and Treatment of High Blood Cholesterol in Adults (Adult Treatment Panel III). JAMA. 2001;285:2486 -97.

8. Cooppan R. Metabolic syndrome and its evolving link to diabetes. Postgrad Med. 2005;118:7-14.

9. Preuss HG, Gondal JA, Lieberman S. Association of macronutrients and energy intake with hypertension. J Am Coll Nutr. 1996;15;21-35.

10. The JNC 7 Report. The Seventh Report of the Joint National Committee on Prevention, Detection, Evaluation, and Treatment of High Blood Pressure. JAMA. 2003; 289:2560-72.

11. Jee-Young Oh, Young Sun Hong, Yeon Ah Sung, Elizabeth Barret-Connor. Prevalence and factor analysis of metabolic syndrome in an urban Korean population. Diabetes Care. 2004; 27:2027-32.

12. Folsom AR, Burke GL, Byers CL, Hutchkinson RJ, Heiss G, Flack JM, Jacobs DR, Caan B,. Implications of obesity for cardiovascular disease in blacks : the CARDIA and ARIC studies. Am J Clin Nutr. 1991;53(6 Suppl):1604S-11S.

13. Siani A, Cappuccio FP, Barba G, Trevisan M, Farinaro E, Lacone R, et al. The relationship of waist circumference to blood pressure: the Olivetti Heart Study. Am J Hypertens. 2002; 15:780-6.

14. Side X, Mingtang S, Shuquan Z, Zhaomei M, Yinzhi X, Yuyun L, et al. Anthropometric and dietary survey of elderly Chinese. Br J Nutr. 1991;66:355-62.

15. Kannel WB. Fifty years of Framingham Study contribution to understanding hypertension. J Hum Hypertens. 2000; 14:83-90

16. Cassano PA. Body fat distribution, blood pressure, and hypertension A prospective cohort study of men in the normative aging study. Ann Epidemiol. 1990;1:33-48.

17. Kannel WB. Risk stratification in hypertension: new insights from the Framingham Study. Am J Hypertens. 2000;13:3S-8S.

18. Zanchetti A. Hyperlipidemia in the hypertensive patient. Am J Med. 1994;96:3S-8S. 